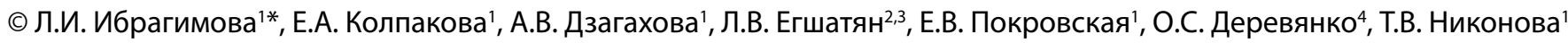

${ }^{1}$ Национальный медицинский исследовательский центр эндокринологии, Москва

${ }^{2}$ Московский клинический научный центр имени А.С. Логинова, Москва

${ }^{3}$ Московский государственный медико-стоматологический университет им. А.И. Евдокимова, Москва

${ }^{4} \mathrm{OОО}$ «КДФ-Запад», Москва

В начале XXI в. с появлением технических возможностей и новых методов секвенирования генов значительно возросло внимание исследователей к изучению метагенома человека. Активно изучается взаимосвязь между изменениями качественного и количественного состава микробиоты кишечника (МК) и различными заболеваниями, ведется поиск специфических метаболитов и генов микроорганизмов, которые могут быть ассоциированы с развитием, в частности, иммуноопосредованных заболеваний. В последние годы опубликовано множество новых данных о возможном вкладе дисбиоза микрофлоры кишечника в развитие сахарного диабета 1 типа (СД1), тогда как первые предположения были высказаны еще в 1970-е годы. Поиск патогенетических механизмов влияния МК на развитие и прогрессирование СД1 становится все более актуальной задачей, так как в последние годы частота возникновения СД1 быстро увеличивается, что является серьезной проблемой здравоохранения во всем мире.

В данном обзоре обсуждаются современные представления о роли МК в иммунопатогенезе СД1, новые данные о ближайших перспективах в изучении макрогенома человека, современные представления о роли МК в иммунопатогенезе СД1 и возможности применения знаний для практикующего врача.

КЛЮЧЕВЫЕ СЛОВА: микробиота; сахарный диабет 1 типа; метагеномное секвенирование

\title{
THE ROLE OF THE GUT MICROBIOTA IN THE DEVELOPMENT OF TYPE 1 DIABETES MELLITUS
}

(c) Liudmila I. Ibragimova1*, Evgenia A. Kolpakova', Agunda V. Dzagakhova', Lilit V. Egshatyan²,3 Elena V. Pokrovskaya1, Olga S. Derevyanko', Tatiana V. Nikonova

'Endocrinology Research Centre, Moscow, Russia

${ }^{2}$ Moscow Clinical Research Center A.S. Loginova, Moscow, Russia

${ }^{3}$ A.I. Yevdokimov Moscow State University of Medicine and Dentistry, Moscow, Russia

${ }^{4}$ Ltd “DFC - West", Moscow, Russia

At the beginning of the XXI century, with the advent of technical capabilities and new methods of genes sequencing, the attention of researchers to the study of the human metagenome has significantly increased. The interaction between changes in the qualitative and quantitative composition of the gut microbiota (GM) and various diseases is being actively studied, a search for specific metabolites and genes of microorganisms that may be associated with the development, in particular, of immune-mediated diseases is underway. In recent years, a lot of new data have been published on the possible contribution of gut flora dysbiosis to the development of Type 1 Diabetes Mellitus (T1DM), while the first assumptions were put forward as far back as 1970s. The search for pathogenetic mechanisms of GM influence on the development and progression of T1DM is becoming an increasingly relevant objective, since in recent years the incidence of T1DM is rapidly increasing, which is a serious health problem throughout the world.

This review discusses the current ideas about the role of GM in the immunopathogenesis of T1DM, new data on the nearterm prospects in the study of the human macrogenome, current ideas about the role of GM in the immunopathogenesis of T1DM, and the possibility of applying this knowledge by the practitioner.

KEYWORDS: microbiota; type 1 diabetes mellitus; gene sequencing

Биологическая среда человека представлена экологическими нишами, заселенными различными типами микроорганизмов. В процессе филогенеза в организме налажена работа ферментов, кодируемых геномами всех симбиотических резидентных микроорганизмов. Они участвуют в контроле оптимального уровня метаболических процессов, создают колонизационную резистентность к условно-патогенным микроорганизмам [1]. В 2011 г. введен термин «микробиом» для характеристики уникальной для каждого человека совокупности всех генов микроорганизмов. Микробиом отражает коллективный геном микробиоты, тогда как микробиота является микробиоценозом внутри определенной среды отдельных органов и систем. Из всех клеток в составе человеческого 
организма до 90\% принадлежит бактериям, населяющим различные биотопы человека (данные Национального института здоровья США, National Institutes of Health, NIH) [2]. Взаимодействие человеческого макроорганизма с микробиотой кишечника (МК), в зависимости от таксономического состава микроорганизмов и метаболитов в процессе их жизнедеятельности, является индикатором здоровья либо детерминантой различных заболеваний [3].

За последнее десятилетие появились данные, указывающие на роль различий в составе, особенностей наследования и функциональных изменений МК, в том числе интродукции определенных микробных групп, в развитии множества заболеваний. Большое внимание направлено на изучение места дисбиоза в патогенезе воспалительных заболеваний кишечника, онкологических заболеваний, рассеянного склероза, болезней печени, ожирения, иммуноопосредованных заболеваний, в том числе сахарного диабета 1 типа (СД1).

Согласно данным Федерального регистра больных сахарным диабетом Российской Федерации, прослеживается тенденция к росту заболеваемости обоих типов СД. Поиск дополнительных этиологических факторов, в том числе вклад измененной МК в патогенез СД1, создает перспективы в разработке мер первичной профилактики и дополнительных методов терапии заболевания.

\section{РОЛЬ МИКРОБИОТЫ КИШЕЧНИКА}

\section{В ЖИЗНЕДЕЯТЕЛЬНОСТИ ОРГАНИЗМА ЧЕЛОВЕКА}

МК называется ассоциация микроорганизмов, которые составляют микроэкологическую систему, населяющую желудочно-кишечный тракт (ЖКТ) [4]. Количество симбиотических микроорганизмов неодинаково в различных отделах ЖКТ и варьирует от $10^{2}$ до $10^{3}$ колониеобразующих единиц в 1 г содержимого (KOE/г) в желудке и до $10^{12}-10^{13} \mathrm{KOE} /\ulcorner$ - в дистальных отделах толстой кишки. Максимальное количество бактерий обнаруживается в слепой и поперечно-ободочной кишках. Основными факторами, ограничивающими размножение бактерий в верхних отделах ЖКТ, являются быстрое продвижение пищевых масс, кислая среда и воздействие протеолитических ферментов [5]. В толстой кишке условия среды диаметрально противоположны, в связи с чем наблюдается большее разнообразие и количество микроорганизмов. Несмотря на разнообразие МК, наличие более 2000 видов микроорганизмов, 93,5\% всего состава принадлежат 5 типам (филам): Firmicutes, Bacteroidetes, Actinobacteria, Proteobacteria, Verrucomicrobia, при этом Firmicutes и Bacteroidetes составляют более 90\% всех представителей МK [6]. Технологический прорыв с возможностью использования шотган-метагеномного секвенирования ознаменовал собой начало широкомасштабных исследований по изучению метагенома человека [7]. МК является наиболее многочисленной и разнообразной в сравнении с микробными сообществами других экологических ниш внутри человеческого организма, поэтому привлекает наибольший интерес ученых со всего мира [8]. В первом десятилетии XXI В. организованы два крупнейших консорциума, ставившие целью расшифровку и изучение функции генов представителей МК человека: MetaHIT (Metagenome of Human Intestinal Tract) в Европе и HMP (Human Microbiome Project) в США [1].
Результаты работы глобальной программы изменили ранние представления об истинном количестве микроорганизмов, населяющих организм человека [9]. Ученые из MetaHIT установили, что человеческий геном содержит около 22000 генов, но, по оценкам НМР, микроорганизмы населяют наш организм в количестве 8 млн генов, что в 360 раз больше генома человека [9].

\section{ФУНКЦИИ КИШЕЧНОЙ МИКРОБИОТЫ}

Функции МК чрезвычайно разнообразны. К ним относятся обеспечение защиты ЖКТ от колонизации патогенными и условно-патогенными микроорганизмами, иммуномодулирующая функция кишечника, участие в энергетическом обмене, участие в процессах нейроэндокринной регуляции слизистой оболочки кишечника, кишечной моторики, продукция короткоцепочечных жирных кислот (КЦЖК), поддержание слабокислой среды в просвете кишечника и продукция ряда витаминов (К, витаминов группы В) [8].

Систематизируя функции МК, следует выделить защитную, пищеварительную, метаболическую и иммуномодулирующую (табл. 1) [5, 8].

\section{ФОРМИРОВАНИЕ МИКРОБИОТЫ КИШЕЧНИКА В ОНТОГЕНЕЗЕ ЧЕЛОВЕКА}

Формирование МК в ходе онтогенеза человека является поэтапным прогрессивным процессом. До недавнего времени считалось, что заселение кишечника ребенка происходит только после рождения и зависит от раннего прикладывания к груди, характера вскармливания, взаимодействия с окружающими его людьми, объектами и с пищей. Однако, согласно современному взгляду, становление МК плода начинается еще до рождения, о чем свидетельствует наличие микробной рРНК в плаценте, околоплодных водах, пуповинной крови и в меконии новорожденных $[6,8]$. Внутриутробный и неонатальный периоды жизни - критические этапы формирования микробиома плода, от которых во многом зависит состояние здоровья человека в течение всей жизни [6, 10]. Начиная с возраста 2-3 лет МК детей практически полностью повторяет по составу МК взрослых, а окончательно формируется к концу пубертатного периода [11]. Первоначальное становление и формирование неонатального микробиома является мультифакторным процессом и во многом зависит от способа родоразрешения, типа вскармливания ребенка, лекарственной терапии, условий окружающей среды [12]. МК детей, рожденных естественным путем, преимущественно представлена вагинальной флорой матери (Prevotella, Sneathia и Lactobacillus) [13]. Во время естественных родов факультативные анаэробы колонизируют кишечник младенца, создавая анаэробную среду в течение первых нескольких дней жизни для роста облигатных анаэробов (таких как Bacteroides и Bifidobacterium) [11, 14, 15]. У детей, рожденных путем кесарева сечения, МК характеризуется скудным видовым разнообразием, низким содержанием Bifidobacterium и Bacteroides, а также наличием бактерий, присутствующих на кожных покровах матери (Staphylococcus, Acinetobacter, Corynebacterium и Propionibacterium) [16]. У этих младенцев чаще 
Таблица 1. Основные функции микробиоты кишечника [5]

Функция МК

1. Пищеварительная
Описание

- Гликолитические ферменты МК расщепляют углеводы пищевых волокон, в результате чего образуются КЦЖК, которые препятствуют размножению патогенных микроорганизмов, регулируют апоптоз и обладают антиканцерогенным эффектом, снижая пролиферацию клеток и повышая их дифференцировку

- Под действием конечных продуктов распада белков, образованных при бактериальном гидролизе протеолитической МК, активизируется кишечная перистальтика

- Формирование колонизационной резистентности по отношению к патогенным и условно-патогенным микроорганизмам за счет образования бактериостатических низкомолекулярных метаболитов (КЦЖК, оксид азота, глутамат, гистамин, серотонин, мурамил дипептид и др.)

2. Защитная

- Деградация бактериальных токсинов, продукция широкого спектра антимикробных веществ

- Блокада клеточных рецепторов - мест прикрепления патогенных микроорганизмов

- Конкуренция с условно-патогенными и патогенными микроорганизмами за питательные субстраты

3. Метаболическая

- Синтез эссенциальных нутриентов: витаминов группы В, витамина K

- Синтез аминокислот: аргинина и глутамина

- Стимуляция созревания лимфоидного аппарата кишечника

4. Иммуномодулирующая · Активация синтеза секреторного иммуноглобулина А

- Стимуляция продукции цитокинов и интерферонов колоноцитами обнаруживаются различные условно-патогенные микробы (Clostridioides, Enterococcus, Klebsiella, Streptococcus, Haemophilus и Veillonella). Также замечено, что при родоразрешении путем кесарева сечения становление МК у детей происходит более длительно. Помимо способа родоразрешения, значимое влияние оказывает тип вскармливания. Грудное вскармливание служит важным фактором в становлении МК, поскольку грудное молоко является главным источником симбиотических бактерий и содержит вещества с антимикробным и пребиотическим потенциалом (бета-лактоза, лактоферрин, олигосахариды, секреторные иммуноглобулины А, лейкоциты, лизоцим и др.) [17]. Фукозилированные олигосахариды, присутствующие в грудном молоке, могут быть использованы Bifidobacterium longum и несколькими видами Bacteroides, позволяя им вытеснять другие бактерии, такие как E. coli и Clostridium perfringens. Микробиота голодных младенцев является незрелой, дисбиотической и содержит большее количество энтеропатогенов, таких как Enterobacteriaceae [1].

Значительное влияние на состав МК также оказывает географическое место проживания ребенка. В многоцентровом исследовании МК у грудных детей пяти европейских стран (Швеции, Шотландии, Германии, Италии и Испании) M. Fallani и соавт. изучали влияние места жительства. Так, у детей, проживающих на севере Европы, выявлено преобладание Bifidobacteria, Clostridiaceae, в то время как в южных регионах - Bacteroides, Eubacteria и Lactobacillus [18].

\section{ДИАГНОСТИКА СОСТАВА КИШЕЧНОЙ МИКРОБИОТЫ}

Установлено, что подавляющее большинство клеток в составе МК не культивируется в известных микро- биологических средах, в настоящее время МК изучают на метагеномном уровне, основанном на секвенировании не только последовательности гена $16 \mathrm{~S}$ рибосомальной РНК (рРНК), но и всех генов и некодирующих участков (полное метагеномное секвенирование и шотган-метагеномика) $[1,19,20]$.

\section{1. Культивирование микроорганизмов}

Традиционные методы выделения и культивирования микроорганизмов путем выращивания на плотных и жидких питательных средах продолжают широко использоваться на практике, однако предоставляют возможность культивировать менее одной трети всей МК и получить данные о ее составе только ее конечной части ЖКТ — толстой кишки [20].

\section{2. Секвенирование гена $16 \mathrm{~S}$ рPHK}

Методы молекулярной биологии активно развивались В течение последних десятилетий [20]. В настоящее время в качестве золотого стандарта анализа состава МК используется секвенирование гена $16 \mathrm{~S}$ рРНК, поскольку этот ген присутствует во всех бактериях [1]. Данный ген характеризуется наличием консервативных и вариабельных участков (доменов), обозначаемых как V1-V9 и различающихся по своей первичной структуре между видами бактерий. Подобная структура гена $16 \mathrm{~S}$ рPHK сделала его удобной мишенью для исследований в области таксономии и эволюции бактерий $[8,14,21]$.

Одно из последних достижений в области диагностики - использование филогенетического микрочипа (чип кишечного тракта человека (the Human Intestinal Tract Chip), HIT-Chip), созданного на основе гипервариабельной области из 1140 уникальных последовательностей рРНК, сгруппированных с использованием сходства 
филотипа из набора более 16000 последовательностей $16 \mathrm{~S}$ рРНК МК человека, который позволяет определять видовой профиль населяющих микроорганизмов, последовательно сменяющих друг друга в процессе жизнедеятельности индивидуума [20].

\section{3. Метагеномное секвенирование}

В качестве альтернативы секвенированию 16S pPHK применяется секвенирование метагенома для достижения более точного, независимого от культур микроорганизмов состава бактериальных сообществ [20]. Использование молекулярно-генетических подходов дает точные результаты даже в тех случаях, когда возбудитель относится к группе некультивируемых микроорганизмов, а также присутствует в небольшом количестве [22]. Полное метагеномное секвенирование используется при сравнительных геномных исследованиях. Метод определения последовательностей ДНК, названный «шотган-метагеномика» («shotgun metagenomics», или «метод «дробовика»), разработанный международным проектом «Геном Человека», дает возможность секвенировать весь выделенный из образца пул нуклеотидов, благодаря чему впервые выявлена полная нуклеотидная последовательность генома человека [20, 22]. Однако высокая стоимость и потребность в дополнительных вычислительных знаниях специалистов делают данные методы труднодоступными. В таблице 2 представлена краткая характеристика методов анализа состава MK [8, 14, 20-22].

\section{ИЗМЕНЕНИЯ ТИПОВОГО СОСТАВА МИКРОБИОТЫ КИШЕЧНИКА ПРИ САХАРНОМ ДИАБЕТЕ 1 ТИПА}

СД1 - иммуноопосредованное эндокринное заболевание с бессимптомным продромальным периодом, характеризующееся абсолютной недостаточностью инсулина в результате разрушения Т-лимфоцитами большей части $\beta$-клеток поджелудочной железы (ПЖ) у генетически детерминированных людей $[20,23]$.
Заболеваемость СД1 значительно увеличилась в большинстве промышленно развитых стран после Второй мировой войны $[19,23]$. Например, в Финляндии в 1950-х годах на 100000 человек ежедневно диагностировались 12 новых случаев СД1 у детей в возрасте до 15 лет, а в 2006 г. этот показатель достиг 65 заболевших на 100000 человек в день, что свидетельствует об увеличении частоты развития СД1 более чем в 5 раз за 55 лет $[19,23]$. Промышленные и экономические достижения в послевоенные годы (улучшение гигиенических условий, диетические изменения и чрезмерное использование антибиотиков), несомненно, имеют решающее значение для иммунного развития [1, 24].

Такой стремительный рост заболеваемости не может быть обусловлен только генетическими факторами, так как для изменения генома требуются сотни лет, соответственно, изменения в образе жизнедеятельности человека должны быть основными причинами увеличения заболеваемости СД1 [23].

Появление специфических панкреатических аутоантител (АТ) в сыворотке крови предшествует манифестации СД1, к ним относятся АТ к глутаматдекарбоксилазе (GAD), тирозинфосфатазе (IA-2), инсулину (IAA), транспортеру цинка 8 (ZnT8 Ab) и островковым клеткам (ICA) [24]. Аутоиммунный процесс, ведущий к развитию СД1, чаще всего инициируется в течение первых лет жизни ребенка, когда МК претерпевает критические этапы динамического развития [23]. В исследовании DIABIMMUNE выявлены различия в составе МК младенцев, у которых впоследствии развился СД1 [25]. Наблюдение за изменениями, предшествующими началу развития заболевания, предполагает, что измененный состав МК играет важную роль в патогенезе и прогрессировании заболевания.

Дисбиоз состава МК представляет собой различные нарушения в микробной экосистеме различных отделов кишечника: избыточный рост одних микроорганизмов и гибель других. Как уже говорилось ранее, Firmicutes и Bacteroidetes составляют более 90\% всех

Таблица 2. Характеристика методов анализа состава микробиоты кишечника

\begin{tabular}{|c|c|c|}
\hline $\begin{array}{c}\text { Метод анализа состава } \\
\text { МК }\end{array}$ & Преимущества & Недостатки \\
\hline $\begin{array}{l}\text { 1. Культивирование } \\
\text { микроорганизмов }\end{array}$ & $\begin{array}{l}\text { - Возможность диагностировать основные } \\
\text { микроорганизмы } \\
\text { • Широкое распространение и доступность } \\
\text { метода }\end{array}$ & $\begin{array}{l}\text { - Возможность культивирования } \\
\text { менее одной трети МК } \\
\text { - Длительное время ожидания } \\
\text { результатов исследования } \\
\text { (около } 10 \text { сут) }\end{array}$ \\
\hline $\begin{array}{l}\text { 2. Секвенирование } \\
\text { гена } 16 \mathrm{~S} \text { рРНК }\end{array}$ & $\begin{array}{l}\text { • Доступность и точность метода } \\
\text { • Возможность распознавания профиля } \\
\text { последовательно сменяющих друг друга } \\
\text { в процессе жизнедеятельности человека видов }\end{array}$ & $\begin{array}{l}\text { - Ограничение в таксономической } \\
\text { идентификации бактериального } \\
\text { агента лишь до рода, а иногда } \\
\text { только до семейства или порядка }\end{array}$ \\
\hline $\begin{array}{l}\text { 3. Метагеномное } \\
\text { секвенирование }\end{array}$ & $\begin{array}{l}\text { • Возможность получения новых сведений } \\
\text { о составе МК и ее метаболической активности } \\
\text { без необходимости выделять и культивировать } \\
\text { бактерии } \\
\text { • Высокая чувствительность и специфичность } \\
\text { • Идентификация труднокультивируемых или } \\
\text { некультивируемых микроорганизмов } \\
\text { • Идентификация микроорганизмов, } \\
\text { присутствующих в небольшом количестве }\end{array}$ & $\begin{array}{l}\text { - Высокая стоимость } \\
\text { - Потребность в высококлассных } \\
\text { специалистах }\end{array}$ \\
\hline
\end{tabular}


представителей МК человека [26]. В результате анализа многочисленных научных публикаций и исследований на предмет дисбиоза МК при СД1 выявлено, что самым распространенным отличием состава МК у пациентов с СД1 является снижение уровней Firmicutes с одновременным повышением Bacteroidetes. Бактерии Firmicutes ответственны за синтез бутирата, защитные и иммуномодулирующие функции которого были раскрыты в предыдущих разделах $[20,21]$. По аналогии со снижением количества Firmicutes выявляется снижение Bifidobacterium, выполняющих схожие с Firmicutes функции: продукция одной из важнейших КЦЖК (бутират), которая участвует в поддержании целостности защитного барьера слизистой оболочки кишечника и оказывает широкий спектр эпигенетических эффектов, влияющих на развитие и функционирование иммунной системы [21, 23, 27]. Также обращает внимание снижение количества лактат-продуцирующих бактерий, обладающих выраженной антагонистической активностью в отношении патогенных и условно-патогенных микроорганизмов.

\section{ИММУНОПАТОГЕНЕЗ РАЗВИТИЯ САХАРНОГО ДИАБЕТА 1 ТИПА ПРИ ДИСБИОЗЕ МИКРОБИОТЫ КИШЕЧНИКА}

Бесспорно, развитие СД1 - мультифакторный процесс: возникновение данного заболевания происходит при генетической предрасположенности и патологическом дисбалансе состава микроорганизмов различных локусов кишечника человека (рис. 1) [21].

Созревание кишечного микробиома тесно связано с развитием иммунной системы. Первые предположения о том, что МК может играть важную роль в развитии иммуноопосредованных заболеваний, таких как СД1, были представлены еще в 1970-1980-х гг. [19]. Точный иммунопатогенез развития СД1 при дисбиозе состава МК в настоящее время неизвестен. Однако есть данные о развитии аномального иммунного ответа на условно-патогенные и/или патогенные микроорганизмы, что может являться триггером развития СД1 при наличии генетических полиморфизмов (наличие $H L A-D R 3 / D R 4$ генов) $[19,24]$.
При дисбиозе МК происходит созревание аутореактивных лимфоцитов, способных взаимодействовать с аутологичными антигенами организма человека. Аутоиммунная агрессия против $\beta$-клеток поджелудочной железы в итоге приводит к повреждению $\beta$-клеток, а при гибели более 80\% клеток - развитию СД1. Схематично иммунопатогенез развития СД1 представлен на рисунке 2 [5, 19, 24].

\section{КИШЕЧНАЯ МИКРОБИОТА У ПАЦИЕНТОВ С САХАРНЫМ ДИАБЕТОМ 1 ТИПА В КЛИНИЧЕСКОЙ ПРАКТИКЕ ЛЕЧАЩЕГО ВРАЧА}

Выяснение общих звеньев этиопатогенеза СД1 позволяет существенно продвинуться в вопросах профилактики возникновения данного заболевания.

МК является не просто ассоциацией микроорганизмов, это многокомпонентная динамичная система с внутренней структурой, активно взаимодействующая с организмом человека. Патогенез возникновения СД1 прямо или косвенно связан с нарушением ферментативного и биохимического равновесия жизнедеятельности нормальной МК и его влиянием на организм индивидуума [20, 22].

В некоторых странах кожа младенцев, рожденных путем кесарева сечения, обрабатывается вагинальной жидкостью матери с целью получения микробиома, сопоставимого по составу с микробиомом детей, рожденных естественным образом, - это метод вагинального посева [21].

При дефиците витамина А в рационе детей увеличивается соотношение Firmicutes/Bacteroidetes (изменение состава MK, обнаруживаемое у многих пациентов с СД1), снижается количество бутират-продуцирующих бактерий, что ведет к дисбиозу МК, нарушению ферментации полисахаридов и продукции КЦЖК, это влияет на развитие патологического иммунного ответа и может способствовать возникновению СД1. В работе, проводимой на поросятах, выявлено, что добавление цинка в рацион питания животных увеличивало бактериальное разнообразие и способствовало стабилизации MK [20].

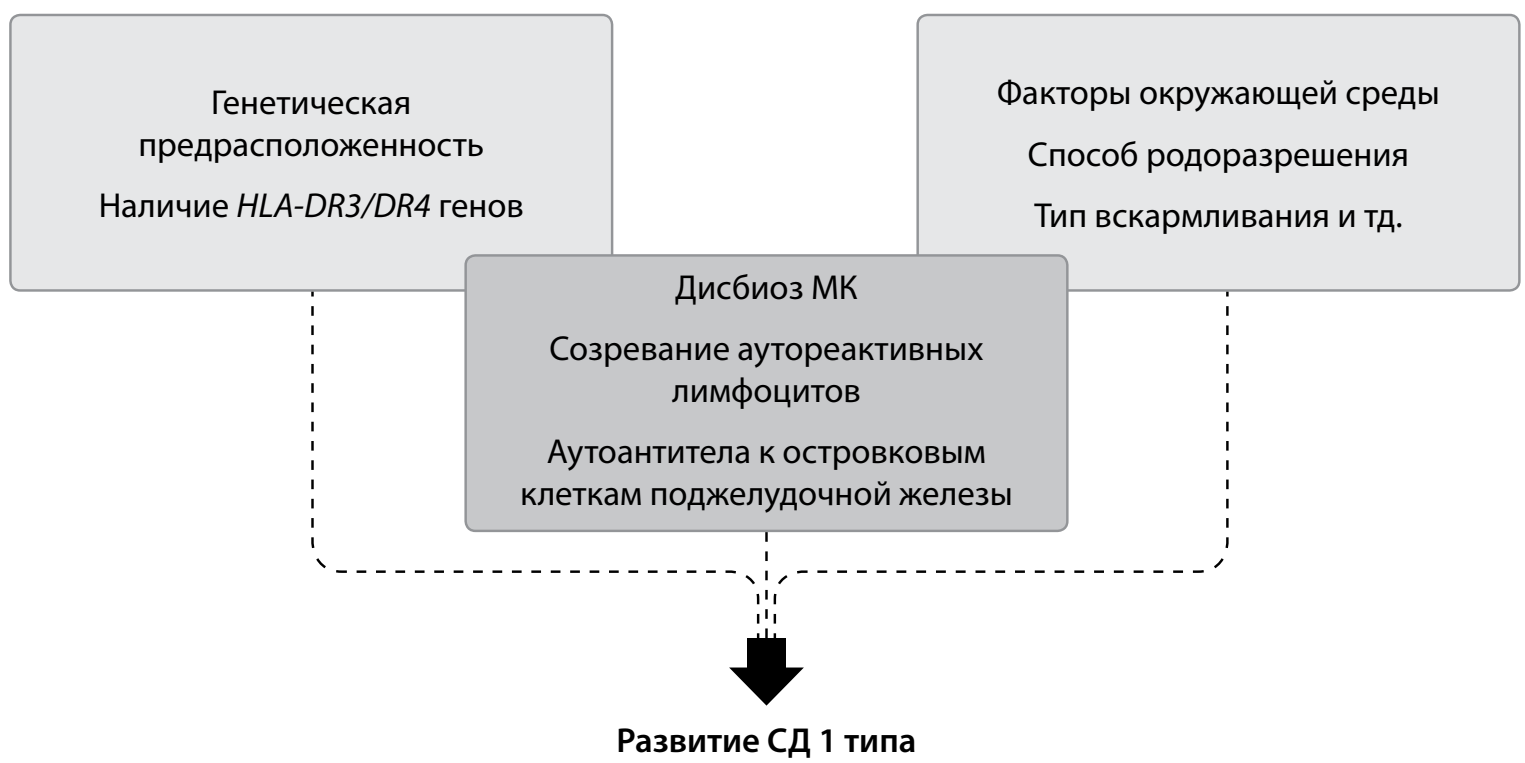

Рисунок 1. Факторы, влияющие на развитие сахарного диабета 1 типа. 


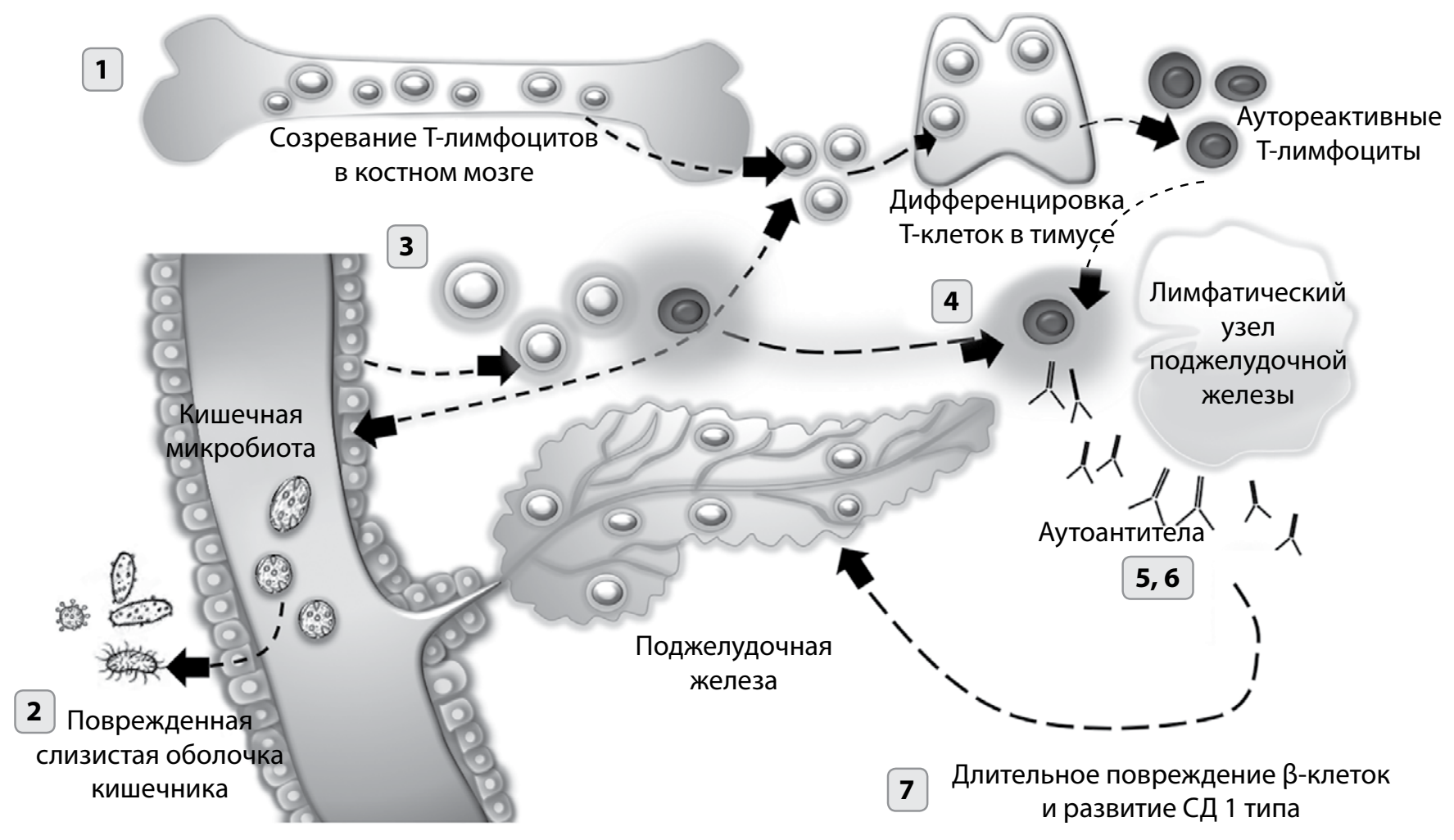

Рисунок 2. Иммунопатогенез развития сахарного диабета 1 типа [4, 18, 23].

1. Гемопоэтические стволовые клетки (предшественники Т-лимфоцитов) из костного мозга мигрируют в тимус, где происходит дифференцировка Т-клеток, генетически детерминированных к взаимодействию с определенным антигеном, с последующим поступлением зрелыхТ-лимфоцитов в кровь [5].

2. При снижении микробного разнообразия нарушается целостность кишечного барьера, повышается проницаемость слизистой оболочки, что может вызвать сбой иммунологической толерантности перекрестно реагирующими микробными антигенами [24, 32].

3. Реализация иммуномодулирующего эффекта МК обусловлена влиянием на дифференцировку Т-клеток в пейеровых бляшках. При аномальном иммунном ответе на комменсальные или патогенные микроорганизмы аутореактивные Т-лимфоциты, активированные перекрестнореагирующими антигенами микроорганизмов, способны распознавать и реагировать с аутоэпитопами собственных клеток организма индивидуума $[5,19,24,32]$.

4. Наивные аутоантиген-специфические Т-лимфоциты (Т-клетки, которые еще не встречались с антигеном) в лимфатических узлах поджелудочной железы распознают фрагменты островковых молекул из поврежденных ß-клеток (например, при инфекционном воспалении, вызванном вирусами и бактериями). Т-клетки памяти помогают В-клеткам, специфичным для аутоантигенов, дифференцироваться в плазматические клетки, которые продуцируют аутоантитела к островковым клеткам поджелудочной железы [5, 19, 24].

5,6.Образование тканевых антигенов и поверхностная экспрессия молекул HLA класса I на поврежденных $\beta$-клетках, представляющих аутоантигены CD8 ${ }^{+}$цитотоксическим Т-клеткам [5, 19, 24]

7. Длительное повреждение $\beta$-клеток поджелудочной железы аутоантителами приводит к потере значительной части функционирующих $\beta$-клеток, в связи с чем развивается СД 1 типа $[5,19,24]$.

В повседневной практике врач сталкивается с необходимостью выбора эффективных и безопасных средств коррекции дисбиоза МК. Детям из группы риска развития СД1 (наличие нескольких АТ по данным лабораторных исследований) в качестве профилактической меры необходимо составление персонализированного рациона питания, сбалансированного по содержанию пищевых компонентов, микронутриентов и макронутриентов для полноценного развития МК ребенка [24]. Дополнительные препараты для коррекции существующих нарушений МК включают пребиотики, пробиотики, синбиотики и метабиотики [1]. Также активно изучается возможность проведения трансплантации фекальной микробиоты (ТФМ) здоровых доноров.

Пребиотики - элементы немикробного состава, ферментирующиеся МК толстого кишечника человека и стимулирующие ее рост и жизнедеятельность $[1,28]$. Представителями этой группы являются полисахариды натурального происхождения [29].

Пробиотики - это живые микроорганизмы, оказывающие влияние на оптимизацию МК [29]. Одним из наиболее ожидаемых результатов пробиотической терапии, наряду с подавлением активности факультативной микробиоты, является нормализация метаболической активности MK [1]. Наиболее перспективными в данном отношении являются пробиотики, содержащие различные штаммы Lactobacillus и Bifidobacterium. Недавнее исследование показало, что ежедневное потребление Lactobacillus reuteri в качестве пробиотического препарата увеличивало секрецию инсулина и инкретина у пациентов с СД [20].

Синбиотики - комбинация пробиотиков и пребиотиков, оказывающая взаимоусиливающее воздействие на обмен веществ в организме человека [1].

Метабиотики являются структурными компонентами пробиотических микроорганизмов и/или их метаболитов, сигнальных молекул с определенной химической структурой; применение метабиотиков позволяет создать управляемый микробиоценоз кишечника, поскольку метаболические, сигнальные, транспортные и другие функции представителей индигенной микробиоты имеют большее значение, чем количественное содержание в биотопе микроорганизмов тех или иных видов [29]. 
ТФМ - введение фекальной суспензии здорового донора в ЖКТ реципиента с целью восстановления стабильности и разнообразия состава МК у пациентов с заболеваниями, связанными с дисбиозом МK [1, 30]. На сегодняшний день основными возможными терапевтическими направлениями ТФМ являются лечение хронических воспалительных заболеваний ЖКТ (наиболее широко применяется для лечения рецидивирующего псевдомембранозного колита, вызванного Clostridium difficile), а также ожирения [31]. В 2018 г. в Китае описан первый случай ТФМ женщине с СД 2 типа (СД2) и диабетической полинейропатией с болевым синдромом и отсутствием положительного ответа на фоне доступных лекарственных средств. После проведенной ТФМ выявлено уменьшение выраженности симптомов (значительное уменьшение болевого синдрома), а также улучшение гликемического контроля с редукцией дозы гипогликемических препаратов. За 2 года последующего наблюдения после проведенной ТФМ пациентка больше не принимала обезболивающих лекарственных средств [30]. Полученные результаты показывают возможность ТФМ в улучшении качества жизни пациентов с СД, в связи с чем ученые продолжают исследования в направлении коррекции дисбиоза МК.

\section{ЗАКЛЮЧЕНИЕ}

Безусловно, расшифровка метагенома человека входит в число фундаментальных открытий современной медицины. Перспективой ближайшего будущего является накопление достаточного количества достоверных данных, устанавливающих роль и причинно-следственные связи между дисбиозом МК и развитием различных иммуноопосредованных заболеваний, в том числе СД1. Важной задачей является использование полученных знаний в клинической практике. Изменения нормальной МК могут быть предикторами различных патологических состояний, поэтому выявление диагностических маркеров позволит разработать практические меры диагностики, профилактики и лечения широкого спектра заболеваний.

\section{ДОПОЛНИТЕЛЬНАЯ ИНФОРМАЦИЯ}

Источник финансирования. Поисково-аналитическая работа по подготовке рукописи проведена при финансовой поддержке гранта российского научного фонда (проект №17-75-30035).

Конфликт интересов. Авторы декларируют отсутствие явных и потенциальных конфликтов интересов, связанных с публикацией настоящей статьи.

Участие авторов. Колпакова Е.А., Дзагахова А.В. - концепция и дизайн работы, сбор и анализ материала, написание текста рукописи; Ибрагимова Л.И. - концепция и дизайн работы, анализ материала, редактирование текста рукописи; Егшатян Л.В. - концепция и дизайн работы, анализ материала, редактирование текста рукописи; Покровская Е.В. - редактирование текста рукописи; Деревянко О.С. - редактирование текста рукописи, Никонова Т.В. - концепция и дизайн работы, редактирование текста рукописи.

\section{СПИСОК ЛИТЕРАТУРЫ | REFERENCES}

1. Микробиота / Под ред. Е.Л. Никонова, Е.Н. Поповой. - М.: Медиа Сфера; 2019. [Mikrobiota. Ed. by Nikonov EL, Popova EN. Moscow: Media Sfera; 2019. (In Russ.)].

2. Афинеевская А.О., Мальков О.А., Говорухина А.А. Роль кишечной микробиоты в патогенезе атеросклероза и перспективные меры профилактики (обзор) // Журнал медико-биологических исследований. - 2020. - Т. 8. - №2. - С. 184-193. [Afineevskaya AY, Mal'kov OA, Govorukhina AA. The Role of Intestinal Microbiota in the Pathogenesis of Atherosclerosis and Promising Preventive Measures (Review). J Med Biol Res. 2020;8(2):184-193. (In Russ.)]. doi: https://doi.org/10.37482/2542-1298-Z009

3. Дзгоева Ф.Х., Егшатян Л.В. Кишечная микробиота и сахарный диабет типа 2 // Эндокринология: новости, мнения, обучение. - 2018. - T. 3. - №24. - C. 55-63. [Dzgoeva FKh, Egshatyan LV. Intestinal microbiota and type 2 diabetes mellitus. Endocrinology: News, Opinions, Training. 2018;7(3):55-63. (In Russ.)]. doi: https://doi.org/10.24411/2304-9529-2018-13005

4. К Каштанова Д.А., Егшатян Л.В., Ткачева О.Н. Участие микробиоты кишечника человека в процессах хронического системного воспаления // Клиническая микробиология и антимикробная химиотерапия. - 2015. - Т. 17. — №4. - C. 310-317. [Kashtanova DA, Egshatyan LV, Tkachyova ON. The Involvement of Human Gut Microbiota in Chronic Systemic Inflammation. Klinicheskaya mikrobiologiya i antimikrobnaya khimioterapiya. 2015;17(4):310-317. (In Russ.)]

5. Булатова Е.М., Богданова Н.М., Лобанова Е.А., Габрусская Т.В. Кишечная микробиота: современные представления // Педиатрия. Журнал им. Г.Н. Сперанского. — 2009. T. 87. —№3 - C. 104-109. [Bulatova EM, Bogdanova NM, Lobanova EA, Gabrusskaya TV. Kishechnaya mikrobiota: sovremennye predstavleniya. Pediatriya. Zhurnal im. GN Speranskogo. 2009;87(3):104-109. (In Russ.)]

6. Moles L, Gómez M, Heilig H, et al. Bacterial Diversity in Meconium of Preterm Neonates and Evolution of Their Fecal Microbiota during the First Month of Life. Sanz Y, ed. PLoS One. 2013;8(6):e66986. doi: https://doi.org/10.1371/journal.pone.0066986
7. Yatsunenko T, Rey FE, Manary MJ, et al. Human gut microbiome viewed across age and geography. Nature. 2012;486(7402):222-227. doi: https://doi.org/10.1038/nature11053

8. Егшатян Л.В., Ткачева О.Н., Кафарская Л.И., и др. Изменения кишечной микрофлоры, ассоциированные с возрастом и образом жизни // Ожирение и метаболизм. - 2015. T. 12. - №2. - C. 3-9. [Egshatyan LV, Tkacheva ON, Kafarskaya LI, et al. The changes of gut microbiota associated with age and lifestyle. Obe Metab. 2015;12(2):3-9. (In Russ.)]. doi: https://doi.org/10.14341/omet201523-9

9. Turnbaugh PJ, Ley RE, Hamady M, et al. The Human Microbiome Project. Nature. 2007;449(7164):804-810. doi: https://doi.org/10.1038/nature06244

10. Ardissone AN, de la Cruz DM, Davis-Richardson AG, et al. Meconium Microbiome Analysis Identifies Bacteria Correlated with Premature Birth. PLoS One. 2014;9(3):e90784 doi: https://doi.org/10.1371/journal.pone.0090784

11. O'Toole PW, Claesson MJ. Gut microbiota: Changes throughout the lifespan from infancy to elderly. Int Dairy J. 2010;20(4):281-291. doi: https://doi.org/10.1016/j.idairyj.2009.11.010

12. Hesla HM, Stenius F, Jäderlund L, et al. Impact of lifestyle on the gut microbiota of healthy infants and their mothers the ALADDIN birth cohort. FEMS Microbiol Ecol. 2014;90(3):791-801. doi: https://doi.org/10.1111/1574-6941.12434

13. Куликов А.В., Шифман Е.М., Беломестнов С.Р., Левит А.Л. Неотложная помощь при преэклампсии и ее осложнениях Эклампсия, HELLP-синдром. Клинические рекомендации // Анестезиология и реаниматология. - 2013. - №5. [Kulikov AV, Shifman EM, Belomestnov SR, Levit AL. Neotlozhnaya pomoshch' pri preeklampsii i ee oslozhneniyakh. Eklampsiya, HELLP-sindrom. Klinicheskie rekomendatsii. Anesteziologiya i reanimatologiya. 2013;5 (In Russ.)]

14. Никонов Е.Л., Гуревич К.Г. Микробиота различных локусов организма. - М.: Российская академия наук; 2017. [Nikonov EL, Gurevich KG. Mikrobiota razlichnykh lokusov organizma. Moscow: Rossiiskaya akademiya nauk. 2017. (In Russ.)]. 
15. Gülden E, Wong FS, Wen L. The gut microbiota and Type 1 Diabetes. Clin Immunol. 2015;159(2):143-153. doi: https://doi.org/10.1016/j.clim.2015.05.013

16. Mueller NT, Bakacs E, Combellick J, et al. The infant microbiome development: mom matters. Trends Mol Med. 2015;21(2):109-117. doi: https://doi.org/10.1016/j.molmed.2014.12.002

17. Garrido D, Ruiz-Moyano S, Mills DA. Release and utilization of $\mathrm{N}$-acetyl-d-glucosamine from human milk oligosaccharides by Bifidobacterium longum subsp. infantis. Anaerobe. 2012;18(4):430-435. doi: https://doi.org/10.1016/j.anaerobe.2012.04.012

18. Fallani M, Young D, Scott J, et al. Intestinal Microbiota of 6-weekold Infants Across Europe: Geographic Influence Beyond Delivery Mode, Breast-feeding, and Antibiotics. J Pediatr Gastroenterol Nutr. 2010;51(1):77-84. doi: https://doi.org/10.1097/MPG.0b013e3181d1b11e

19. Siljander H, Honkanen J, Knip M. Microbiome and type 1 diabetes. EBioMedicine. 2019;46:512-521. doi: https://doi.org/10.1016/j.ebiom.2019.06.031

20. Han H, Li Y, Fang J, et al. Gut Microbiota and Type 1 Diabetes. Int J Mol Sci. 2018;19(4):995. doi: https://doi.org/10.3390/ijms19040995

21. Durazzo M, Ferro A, Gruden G. Gastrointestinal Microbiota and Type 1 Diabetes Mellitus: The State of Art. J Clin Med. 2019;8(11):1843. doi: https://doi.org/10.3390/jcm8111843

22. Алексеева А.Е., Бруснигина Н.Ф. Возможности и перспективы применения методов массивного параллельного секвенирования в диагностике и эпидемиологическом надзоре за инфекционными заболеваниями // Журнал МедиАль. 2014. - T. 2. - №12. - C. 6-28. [Alekseeva AE, Brusnigina NF. Possibility and perspectives of massive parallel sequencing methods application in the diagnostics and epidemiological surveillance of infection diseases. Zhurnal MediAl'. 2014;2(12):6-28. (In Russ.)].

23. Knip $M$, Siljander $\mathrm{H}$. The role of the intestinal microbiota in type 1 diabetes mellitus. Nat Rev Endocrinol. 2016;12(3):154-167. doi: https://doi.org/10.1038/nrendo.2015.218
24. Ilonen J, Lempainen J, Veijola R. The heterogeneous pathogenesis of type 1 diabetes mellitus. Nat Rev Endocrinol. 2019;15(11):635-650. doi: https://doi.org/10.1038/s41574-019-0254-y

25. Costa FRC, Françozo MCS, de Oliveira GG, et al. Gut microbiota translocation to the pancreatic lymph nodes triggers NOD2 activation and contributes to T1D onset. J Exp Med. 2016. doi: https://doi.org/10.1084/jem.20150744

26. Macfarlane S, Macfarlane GT. Regulation of short-chain fatty acid production. Proc Nutr Soc. 2003;62(1):67-72. doi: https://doi.org/10.1079/PNS2002207

27. Paparo L, di Costanzo M, di Scala C, et al. The Influence of Early Life Nutrition on Epigenetic Regulatory Mechanisms of the Immune System. Nutrients. 2014;6(11):4706-4719. doi: https://doi.org/10.3390/nu6114706

28. Gibson GR, Roberfroid MB. Dietary Modulation of the Human Colonic Microbiota: Introducing the Concept of Prebiotics. J Nutr. 1995;125(6):1401-1412. doi: https://doi.org/10.1093/jn/125.6.1401

29. Ардатская М.Д., Столярова Л.Г., Архипова Е.В., Филимонова О.Ю. Метабиотики как естественное развитие пробиотической концепции // Трудный пачиент. — 2017. — Т. 15. — № 6-7. [Ardatskaya MD, Stolyarova LG, Arkhipova EV, Filimonova OYu. Metabiotics as a natural development of a probiotic concept. Trudnyi patsient. 2017;15(6-7). (In Russ.)].

30. Cai T, Ye $\mathrm{X}$, Yong $\mathrm{H}$, et al. Fecal microbiota transplantation relieve painful diabetic neuropathy. Medicine (Baltimore). 2018;97(50):e13543. doi: https://doi.org/10.1097/MD.0000000000013543

31. Lübbert C, Salzberger B, Mössner J. Fäkaler Mikrobiomtransfer. Internist (Berl). 2017;58(5):456-468. doi: https://doi.org/10.1007/s00108-017-0203-6

32. Клиническая патофизиология / Под ред. Черешнева В.А. Литвицкого П.Ф., Цыгана В.Н. - М.: Литрес; 2018. [Klinicheskaya patofiziologiya. Ed. by Chereshnev VA, Litvitsky P.F., Tsygan VN. Moscow: Litres; 2018. (In Russ.)].

\section{ИНФОРМАЦИЯ ОБ АВТОРАХ [AUTHORS INFO]}

* Ибрагимова Людмила Ибрагимовна, к.м.н. [Liudmila I. Ibragimova, MD, PhD]; адрес: Россия, 117036, Москва, ул. Дм. Ульянова, д. 11 [address: 11, Dm. Ulyanova street, 117036 Moscow, Russia];

ORCID: https://orcid.org/0000-0003-3535-520X; eLibrary SPIN: 5013-8222; e-mail: ibragimovaliudmila@gmail.com

Колпакова Евгения Александровна, аспирант [Evgenia A. Kolpakova, MD, PhD student]; ORCID: https://orcid.org/0000-0003-2283-8958; eLibrary SPIN: 5040-8628; e-mail: colpakova.ev@mail.ru Дзагахова Агунда Владимировна, ординатор [Agunda V. Dzagakhova, clinical resident]; ORCID: https://orcid.org/0000-0003-4699-5536; e-mail: ag.dzagahova@yandex.ru Егшатян Лилит Ваниковна, К.M.н. [Lilit V. Egshatyan, MD, PhD]; ORCID: https://orcid.org/0000-0001-8817-1901; eLibrary SPIN: 4552-5340; e-mail: lilit.egshatyan@yandex.ru

Покровская Елена Владиславовна, н.c. [Elena V. Pokrovskaya]; ORCID: https://orcid.org/0000-0001-5268-430X; eLibrary SPIN: 8769-5010; e-mail: pokrovskaya.93@mail.ru

Деревянко Ольга Сергеевна, К.M.H. [Olga S. Derevyanko, MD, PhD]; ORCID: http://orcid.org/0000-0002-3222-6990; eLibrary SPIN: 9977-7856; e-mail: olgader14@mail.ru

Никонова Татьяна Васильевна, Д.М.н. [Tatiana V. Nikonova, MD, PhD]; ORCID: https://orcid.org/0000-0001-5656-2596; eLibrary SPIN: 8863-0201; e-mail: tatiana_nikonova@mail.ru

\section{ЦИТИРОВАТЬ:}

Ибрагимова Л.И., Колпакова Е.А., Дзагахова А.В., Егшатян Л.В., Покровская Е.В., Никонова Т.В. Роль микробиоты кишечника в развитии сахарного диабета 1 типа // Сахарный диабет. — 2021. — Т. 24. — №1. — С. 62-69. doi: https://doi.org/10.14341/DM10326

\section{TO CITE THIS ARTICLE:}

Ibragimova LI, Kolpakova EA, Dzagakhova AV, Egshatyan LV, Pokrovskaya EV, Nikonova TV. The role of the gut microbiota in the development of type 1 diabetes mellitus. Diabetes Mellitus. 2020;24(1):62-69. doi: https://doi.org/10.14341/DM10326 